\title{
Modelling THE RANd ANd Commodity Prices: A Granger Causality and Cointegration Analysis
}

\author{
Eric Schaling
}

Wits Business School

Xolani Ndlovu

Wits Business School

Paul Alagidede

Wits Business School

Accepted: July 2014

\begin{abstract}
This paper examines the 'commodity currency' hypothesis of the Rand, that is, the postulate that the currency moves in line with commodity prices, and analyses the associated causality using nominal data between 1996 and 2010. We address both the short run and long run relationship between commodity prices and exchange rates. We find that while the levels of the series of both assets are difference stationary, they are not cointegrated. Further, we find the two variables are negatively related, with strong and significant causality running from commodity prices to the exchange rate and not vice versa, implying exogeneity in the determination of commodity prices with respect to the nominal exchange rate. The strength of the relationship is significantly weaker than other OECD commodity currencies. We surmise that the relationship is dynamic over time owing to the portfolio-rebalance argument and the Commodity Terms of Trade (CTT) effect and, in the absence of an error correction mechanism, this disconnect may be prolonged. For commodity and currency market participants, this implies that while futures and forward commodity prices may be useful leading indicators of future currency movements, the price risk management strategies may need to be recalibrated over time.
\end{abstract}

Key words: commodity currency, currency commodity, cointegration, causality, VAR

JEL: F310

\section{1}

\section{Introduction}

The relationship between the Rand real exchange rate and commodity prices has been investigated in the past, but we have been unable to find a study specifically focused on this relationship or its associated causality using nominal data. There may be a justification though, for the paucity of literature in this research area. One could be the relatively short data series of a unified floating Rand since $1995 .^{1}$ Empirical exchange rate models are mainly concerned with the behaviour of floating exchange rates between countries which are open to trade and have liberalized capital markets, where the currency values are most likely to reflect various macroeconomic market forces. It is perhaps important now to give the unified Rand a chance some eighteen years after the abolition of the dual exchange rate regime. Exchange rates and economic fundamentals such as commodity prices have grown in importance in the past decade as transmitters of shocks from the global economy on account of integration and proliferation of free trade.

South Africa is a major commodity exporting ${ }^{2}$ economy and it is partly for this reason that the Rand is nonchalantly referred to as a 'commodity currency' in financial markets. The 'commodity currency' tag owes its roots to the pervasive hypothesis that there is comovement between the exchange rates of 
primary commodity producing countries and world commodity prices. Other major industrialised commodity producers with 'commodity currencies' include Australia, New Zealand and Canada. ${ }^{3}$ OECD commodity currencies have a relatively long floating history compared to South Africa - perhaps the reason why there is an abundance of studies examining their relationship with commodity prices. It is on these major commodity currencies that the theory on commodity prices and exchange rates has been built.

Using a bivariate model we attempt to investigate the link between the nominal exchange rate of the Rand and commodity prices. We specifically investigate if commodity prices explain the behaviour of the exchange rate ${ }^{4}$ and, conversely, whether the exchange rate belongs in the commodity prices equation using nominal data. We conjecture that investigating the relationship at the nominal level is valuable, since these are the readily observable variables in the market that inform most spot transaction decisions in the economy. Further, Chen and Rogoff (2003) show that in an open economy model with sticky consumer prices, (which is plausible for South Africa) the nominal exchange rate has to adjust to preserve efficient resource allocation in the event of a commodity market boom. ${ }^{5} \mathrm{We}$ also seek to find if there is a long-run equilibrium relationship between the two asset classes and investigate the existence and direction of causality. We offer some strategies for hedging price risk on the two asset markets and recommendations for the conduct of monetary policy.

This paper is based on the model of Simpson (2002), which posits endogeneity in the joint determination of the exchange rate and commodity prices and allows us to ascertain the existence of Granger causality. More specifically we employ a VAR model, the Engle-Granger and Johansen Cointegration methods on fifteen years of South African Rand data to explore the short- term and longrun equilibrium relationships between these two asset classes. We find empirical evidence consistent with Simpson (2002), showing that US Dollar denominated nominal commodity price returns are negatively related to the nominal Rand Dollar exchange rate with significant causality running from commodity prices to the exchange rate and not vice versa. This means that higher commodity prices are associated with an appreciating exchange rate. Further, we find that the two nominal asset prices are not cointegrated. In comparison, the relationship between the two asset markets is significantly weaker for South Africa than in other commodity producers, such as Australia. More specific, we find that a 1 per cent rise in nominal commodity prices is associated with a 0.3 per cent appreciation of the nominal exchange rate compared to 0.9 per cent for the Australian dollar found by Simpson (2002).

The remainder of this paper is organized as follows. Section 2 reviews the literature while the Section 3 presents the theoretical framework. The econometric methodology and description of the time series data are presented in Section 4. Empirical results are presented and discussed in Section 5, and Section 6 concludes.

\section{2}

\section{Literature review}

In our review of the literature, we find a dichotomy between 'commodity currencies' and 'currency commodities'. On one hand the commodity currency literature focuses on the causal link between commodity prices and currency values. The currency commodities literature on the other hand discusses the reciprocal link, that is, the impact of exchange rates on commodity prices. We discuss the two strands of literature and provide a synthesis of the two, that is, a two-way interaction of the two asset prices, which forms the basis of our study.

\subsection{Currency commodities}

To explore the mutual relationships between exchange rates and commodity prices, Clements and Fry (2006) consider a country which has a commodity currency ${ }^{6}$ and is large enough a producer of a particular commodity that it has sufficient clout to influence world commodity prices. ${ }^{7}$ A commodity boom appreciates the country's currency, thereby making the country's exports expensive to foreigners (assuming the country invoices in domestic currency). ${ }^{8}$ As a result the country's exporters are squeezed and 
export volumes fall. But if the country is a sufficiently large producer of a given commodity, the reduced exports have the effect of increasing world prices further. Thus the appreciation of the currency leads to a still higher world price and a further appreciation. The interaction of the commodity currency and pricing power leads to an amplification of the initial commodity boom.

To convey the symmetric relationship with commodity currencies, Clements and Fry (2006) note that commodities whose prices are substantially affected by currency fluctuations can be called 'currency commodities'.

\subsection{Commodity currencies}

Another link between the two asset markets comes from the portfolio-balance model discussed in Chen (2002). This class of models treat domestic and foreign assets as imperfect substitutes. This means that exchange rates are dependent on the supply and demand for all foreign and domestic assets, not just money. For an economy that relies heavily on commodities for export earnings (which is relevant for South Africa), a boom in world commodity markets would typically lead to a balance-ofpayments surplus and an accumulation of foreign reserves, exerting upward pressure on the relative demand for their home nominal exchange rates. The demand pressure would then lead to a nominal appreciation of the domestic currency. Chaban (2009) characterizes a boom in commodity prices as a transfer of wealth from commodity importing to commodity-exporting countries.

MacDonald and Ricci (2002) employ the Johansen cointegration methodology to find the equilibrium real exchange rate of the Rand. Noteworthy in their study is the inclusion of commodity prices as an explanatory variable for the real effective exchange rate. They find that a 1 per cent increase in real commodity prices is associated with an appreciation of the real effective exchange rate of the Rand of 0.5 per cent. Other explanatory variables found to belong in the real exchange rate equation include interest rate differentials, trade openness, the fiscal balance and the extent of net foreign assets. Their findings are consistent with the findings of Bhundia and Ricci (2004), who employ the standard currency crisis metho- dology of Eichengreen, Rose and Wyplosz (1996), and find that a 1 per cent fall in the price of commodities exported by South Africa is associated in the long run with a real exchange rate depreciation of 0.5 per cent.

Frankel (2007b) sought to find the equilibrium value of the South African Rand over the period 1984-2006 using real exchange rate data. The author finds that economic fundamentals, especially the real prices of South African mineral commodities, are significant and important. We consider his finding important and paving the way for further studies to improve knowledge about this relationship. An implication of his finding is that the 2003-6 real appreciation of the Rand can be (partly) attributed to the Dutch disease phenomenon, that is, partly attributable to growth in export revenues from commodities.

In the context of developed economies, Chen (2002) investigates the empirical disconnect between nominal exchange rates and economic fundamentals. In the study, some macro-models augmented by commodity prices for three OECD economies - Australia, New Zealand and Canada - are tested. In contrast to the literature characterized by notoriously poor in-sample fits and out-of-sample forecast failures, the author finds that for three major OECD primary commodity producers, nominal exchange rates exhibit a robust response to movements in the world prices of their corresponding commodityexports. ${ }^{9}$ Further, he finds that incorporating commodity export prices into standard nominal exchange rate models can generate a marked improvement in their in-sample performance, a significant boost of the commodity currency hypothesis.

Bleaney (1996) employs ninety-two years of Australian data to find out how real exchange rates of primary commodity exporters reacted to changes in the relative prices of their exports. The results show a significant negative correlation between these two variables. ${ }^{10}$ Oddly though, the real Australian dollar exchange rate did not show the significant downward trend observed in the commodity prices. To solve this paradox, Bleaney then used a pure time series analysis of the respective series and concluded that the apparent long-run decline in the relative price of primary commodities was due to an 
inadequate quality adjustment in the price series for manufacturers.

Chen and Rogoff (2003), employ a Dynamic Ordinary Least Squares (DOLS) methodology to investigate the determinants of real exchange rate movements for three OECD economies (Australia, Canada, and New Zealand). They find evidence that suggests a strong and stable influence of the US Dollar world prices of commodity exports on the real exchange rates of the three countries. They note that because commodity products are transacted in highly centralized global markets, an exogenous source of terms of trade fluctuations can be identified for these major commodity exporters. Their findings for Australia and New Zealand especially, are of particular relevance to many developing countries which rely heavily on commodity exports, such as South Africa.

Another relevant contribution is Hatzinikolaou and Polasek (2003) who use post-float nominal Australian data (184:2003) and conclude that the nominal Australian dollar is indeed a commodity currency, with a long-run elasticity of the exchange rate with respect to commodity prices estimated at 0.939 . This finding is consistent with Chen (2002), and Chen and Rogoff (2003), with the former using nominal and the latter using real exchange rate data. The long-run elasticity that they found was higher than the 'conventional wisdom' elasticity of 0.5 (see Clements \& Freebairn, 1991:1). Here the presence of cointegration is, however, in conflict with Simpson (2002), who found no evidence of cointegration in his bivariate model. $^{11}$

\subsection{A synthesis}

For South Africa there is a general dearth in the literature that considers the simultaneous interactions of the commodity and currency markets. This literature gap exists despite the value that reciprocal feedback between the two markets may add to our understanding of their operations. We consider here the few papers that tie together the simultaneous working of the two markets.

Simpson (2002) investigates the joint functioning of commodity and exchange rate markets using a bivariate VAR model. He employs fifteen years of Australian data to investigate the relationship between the nominal Australian Dollar exchange rate and nominal commodity prices. Using the Engle-Granger cointegration methodology, he finds that the variables exhibit dual causality and negative correlation (-0.8952), with the significantly stronger causality running from commodity prices to the exchange rate, findings consistent with Chen and Rogoff (2003).

Another attempt at analysing the joint working of the two markets was done by Swift (2004). The author starts with the analysis of Ridler and Yandle (1972) that deals with the dependence of the world price of a certain commodity on the ' $\mathrm{N}$ ' exchange rates in the world. It is noted that if an individual exporting country is 'small', then a change in the value of its currency has no impact on the world price. The author supposes that there is a boom that exogenously increases the world price of a certain commodity, such that a number of small countries producing the commodity are all hit simultaneously by a common shock that improves their terms of trade. Assuming that all small countries have commodity currencies, then their exchange rates appreciate and the Ridler and Yandle framework implies that there is a subsequent increase in the world price of the commodity they export. Therefore there is both the initial terms-of-trade shock and then a subsequent reinforcing move related to the commodity-currency mechanism. This way, the terms of trade is endogenous, even though the countries are all small individually.

Clements and Fry (2006) employ the Kalman filter to jointly estimate the determinants of the Australian, New Zealand, Canadian Dollar exchange rates and commodity prices. Allowing for spill-over effects between the two asset classes and employing nominal data, their model suggests that commodity returns are more affected by the currency factor than vice versa. Their model is appealing in so far as it contrasts with most papers which do not consider commodity prices endogenously determined by the exchange rate. Their findings also suggest that there is growing market power of OECD economies in the world commodity market. Caveats aside, their model also suggests that exchange rate models failing to account for endogeneity between commodity and currency returns may be misspecified. 
Identifying the elusive link between economic fundamentals and exchange rates is, however, not an easy task and may indeed be unrewarding (Simpson, 2002). Research over the past two decades has repeatedly demonstrated the empirical failures of various structural exchange rate models. Chen (2002) notes that when tested against data from major industrialized economies over the floating exchange rate period, canonical exchange rate models produce notoriously poor in-sample estimations, judged by both standard goodness- of-fit criteria and signs of estimated coefficients. Since Meese and Rogoff (1983) first demonstrated that none of the fundamentals-based structural models could reliably outperform a simple random walk in out-of-sample forecasts, numerous subsequent research attempts have not been able to convincingly overturn this finding. It is these empirical challenges that led Frankel and Rose (1995) to conclude with doubts about the value of further time-series modelling of exchange rates at high or medium frequencies using macroeconomic models.

In Chen and Rogoff (2003), exchange rate modelling is described as one of the most controversial issues in international finance. The research area abounds with empirical puzzles such as the Meese-Rogoff (1983) forecasting puzzle and purchasing power parity theories. Frankel and Rose (1995) and Froot and Rogoff (1995) in their comprehensive survey of the literature summarize the various difficulties in empirically relating exchange rate behaviour to shocks in macroeconomic fundamentals. Pilbeam (1998) notes substantial econometric problems involved in fundamental modelling of exchange rates which are difficult to overcome. For example, fundamental models have estimation problems including misspecification, the models themselves not being linear or they may have omitted variables bias (Meese, 1990). Evidence supporting the purchasing power parity (PPP) hypothesis for example is inconclusive and mixed (Simpson, 2002). Also depending on whether one employs real or nominal variables, the results are mixed and difficult to generalize. ${ }^{12}$

Notwithstanding these problems and criticism, fundamental exchange rate models have been, and continue to be, popular among economic researchers. The ultimate objective is to find the information that can assist in profitable currency risk management, and forecasting for firms. Exchange rate risk management is a constant that firms and monetary policy makers always must deal with consistently. Further, the growing importance of commodity prices and exchange rates as transmitters of shocks, particularly to developing countries like South Africa, presents a compelling need for understanding the actual behaviour of these variables and building adequate theoretical models capable of mimicking empirical evidence. While South Africa abandoned monetary targeting in favour of inflation targeting in 2000 , there is still concern over the realeconomy effects of the value of the Rand exchange rate and its volatility. There have been suggestions for modification of this policy and calls to weaken the Rand to avert job losses (Frankel, 2007a). In this context Kabundi and Schaling (2013) find that for the period 1994-2011 there is robust statistical evidence that - in the long-run - net exports are boosted by a weaker real effective exchange rate. However, this effect does not hold in the short run. Thus, they find empirical evidence supporting the J-curve effect for South Africa. In terms of the trade-off between a higher inflation rate and a more competitive exchange rate, they find that such a trade-off exists in the long run but not in the short run.

Chen, Rogoff and Rossi (2010) show that 'commodity currency' exchange rates have robust power in predicting global commodity prices, both in-sample and out-of-sample, and against a variety of alternative benchmarks. They also explore the reverse relationship (commodity prices forecasting exchange rates) but find it to be notably less robust. They offer a theoretical resolution, based on the fact that exchange rates are strongly forward-looking, whereas commodity price fluctuations are typically more sensitive to short-term demand imbalances.

Finally, Arezki, Dumitrescu, Freytag and Quintyn (2012) examine the relationship between South African Rand and gold price volatility using monthly data for the period 1980-2010. Their main findings are that prior to capital account liberalization the causality runs from the South African Rand to gold price volatility, but the causality runs the other way 
around for the post-liberalization period. These findings suggest that gold price volatility plays a key role in explaining both the excessive exchange rate volatility and a disproportionate share of speculative (short-run) inflows that South Africa has been coping with since the opening up of its capital account.

\section{3}

\section{Theoretical framework ${ }^{13}$}

We employ the framework developed by Simpson (2002). The model assumes a relatively large, open, commodity exporting economy. ${ }^{14} \mathrm{We}$ consider an economy which produces one exportable commodity. The exportable good is associated with the production of primary commodities (agriculture and mineral products). We assume that the terms of trade for this good plays a key role in the determination of the country's real exchange rate in line with the work of De Gregorio and Wolf (1994) and Obstfeld and Rogoff (1996). For such an economy, a boom in commodity prices would exert upward pressure on the real exchange rate through its effect on wages and demand for non-traded goods through a channel similar to the standard BalassaSamuelson effect. Assuming that nominal consumer prices are sticky and unable to respond to the upward pressure induced by a positive terms of terms shock as in Dornbusch (1976), the nominal exchange rate would need to appreciate to restore efficient allocation of resources.

We also consider the country to be a dominant exporter of the commodity. ${ }^{15}$ To demonstrate the link between the exchange rate and international commodity prices, we suppose there is a major depreciation of the currency of the country. If costs do not rise equi-proportionally, so that it is a real depreciation, the improved revenue enhances the bottom line of exporters, and domestic producers of the commodity have an incentive to expand production and export more. But the expansion of exports depresses the world price as, by assumption, the country is the dominant exporter of the commodity. In this case, the depreciation of the currency leads to a depression of the world price. For such an economy, therefore, the exchange rate influences the world price of the commodity.

Sjaastad and Scacciavillani (1993) have elaborated this framework and considered a number of implications of this rich framework in a series of papers. ${ }^{16}$ The starting point is given by the following Vector Autoregressive Model VAR (p): ${ }^{17}$

$$
\begin{aligned}
& E_{t}=v_{0}+\sum_{i=0}^{p} v_{i} E_{t-i}+\sum_{i=0}^{p} \theta_{i} C_{t-i}+e_{t} \\
& C_{t}=\mu_{0}+\sum_{i=0}^{p} \mu_{i} C_{t-i}+\sum_{i=0}^{p} \sigma_{i} E_{t-i}+u_{t}
\end{aligned}
$$

where, $E_{t}$ is the natural log of the exchange rate at time $\mathrm{t}$

$C_{t}$ is the natural log of Commodity prices at time $\mathrm{t}$.

and $\mathrm{p}$ is the maximum lag length

Equation (1) depicts the standard 'commodity currency' argument while equation (2) shows the 'currency commodity' notion of Clements and Fry (2006). The VAR allows us to model important properties of the behaviour of the time series, that is, whether the variables are stationary and/or cointegrated and Granger causality (Granger, 1988). The VAR also implies endogeneity in the determination of the two assets prices with respect to each other, a necessary condition for us to investigate bidirectional Granger causality.

If the variables are non-stationary, it is reasonable to expect that the error term $\left(e_{t}=E_{t}-\alpha-\beta C_{t}\right)$ will also be non-stationary and it cannot be a serially uncorrelated random error with constant variance (Simpson, 2002). If $E_{t}$ and $C_{t}$ are both integrated of a similar order, and combination of them is stationary, the series are said to be cointegrated. Cointegration can be viewed as the statistical expression of the nature of long-run equilibrium relationships. If $E_{t}$ and $C_{t}$ are linked by some long-run relationship, from which they can deviate in the short run but must return to in the long run, residuals will be stationary and the variables will exhibit co-trending behaviour.

If cointegration does not exist between the two variables, the VAR can be reformulated in first differences and OLS methodology applied without running into spurious regression problems. If the series are non-stationary and 
cointegrated, then a long run multiplier, that is, the long-run influence of commodity prices on the exchange rate and vice versa can be estimated. The short-run relationship between them can be expressed as a Vector Error Correction Model (VECM). ${ }^{18}$ Existence of cointegration allows us to analyse the long run relationship of the two asset prices using an
Error Correction Model. Rewriting equations (1) and (2) as a VAR (1):

$$
\begin{aligned}
& E_{\mathrm{t}}=\vartheta_{0}+\vartheta_{1} E_{t-1}+\varphi_{1} C_{t-1}+e_{t} \\
& C_{t}=\mu_{0}+\mu_{1} C_{t-1}+\sigma_{1} E_{t-1}+u_{t}
\end{aligned}
$$

Subtracting $E_{t-1}$ and $C_{t-1}$ from both sides of equation (3) and (4) respectively, yields the following equations:

$$
\begin{aligned}
\Delta E_{t} & =E_{t}-E_{t-1}=\vartheta_{0}+\left(\vartheta_{1}-1\right) E_{t-1}+\varphi_{1} C_{t-1}+e_{t} \\
\Delta C_{t} & =C_{t}-C_{t-1}=\mu_{0}+\left(\mu_{1}-1\right) C_{t-1}+\sigma_{1} E_{t-1}+u_{t}
\end{aligned}
$$

It can be shown that if the exchange rate and commodity prices both have unit roots and if they are cointegrated the coefficients in

Equations 5 and 6 must satisfy the following restrictions:

$$
\begin{gathered}
\vartheta_{1}=1+\frac{\varphi_{1} \mu_{1}}{\sigma_{1}-1} \operatorname{Setting} \beta_{2}=\frac{1-\sigma_{2}}{\mu_{1}} \text { and } \gamma_{1}=\frac{\varphi_{1} \mu_{1}}{\sigma_{1}-1} \text { and } \gamma_{2}=\mu_{1} \\
\text { and } \vartheta_{0}^{*}=\vartheta_{0}+\gamma_{1} \beta_{1} \text { and } \mu_{0}^{*}=\mu_{0}+\gamma_{2} \beta_{1}
\end{gathered}
$$

And when these restrictions are substituted into equations (5) and (6) we get:

$\Delta E_{t}=\vartheta_{0}^{*}+\gamma_{1}\left(E_{t-1}-\beta_{1}-\beta_{2} C_{t-1}\right)+e_{t}$

$\Delta C_{t}=\mu_{0}^{*}+\gamma_{2}\left(E_{t-1}-\beta_{1}-\beta_{2} C_{t-1}\right)+u_{t}$

This representation of the VAR is called an Error Correction Model (ECM) and says that changes in exchange rates and commodity prices from period $t$ - 1 to $t$ both depend on the quantity: $\varepsilon_{t}=E_{t-1}-\beta_{1}-\beta_{2} C_{t-1}$. This quantity represents deviation $\varepsilon$, in period $\mathrm{t}-1$, from the long-run equilibrium path: $E=\beta_{1}+\beta_{2} C$.

Thus, changes in exchange rates and commodity prices (or corrections to exchange rates and commodity prices) depend on the magnitude of the departure of the system from its long-run equilibrium in the previous period. The shocks $e$ and $u$ lead to short-term departures from the cointegrating equilibrium path and then there is a tendency to correct back to equilibrium.

Finally, causality and its direction can be tested between the two variables. We employ the Granger causality test (Engle \& Granger, 1987). Granger (1988) observed that cointegration between two or more variables is sufficient for the presence of causality in at least one direction. 'Granger causality' is a term for a specific notion of causality in timeseries analysis. ${ }^{19}$ The idea of Granger causality is a simple one: A variable $\mathrm{X}$ Granger-causes $\mathrm{Y}$ if $\mathrm{Y}$ can be better predicted using the histories of both $\mathrm{X}$ and $\mathrm{Y}$ than it can using the history of $\mathrm{Y}$ alone. Conceptually, the idea has several components:

- Temporality: Only past values of $X$ can 'cause' Y and vice versa.

- Exogeneity: Sims (1980) points out that a necessary condition for $\mathrm{Y}$ to be exogenous with respect to $X$ is that $X$ fails to Grangercause Y.

- Independence: Similarly, variables X and Y are only independent if each fails to Granger-cause the other.

- Granger causality is thus quite useful, in that it allows one to test for relationships that one might otherwise assume away or otherwise take for granted. ${ }^{20}$

VAR analysis, cointegration, and the EngleGranger Test have firm roots in the exchange rate modelling literature. Prominent examples include Cheung and Lai (1993a, b), Martinez (1999) for Mexico ${ }^{21}$, Cheng (1999) and Simpson (2002). Cheung and Lai (1993a, b), Im, Pesaran and Shin (1995), Wu (1996), Wu and Chen (1999), Maddala and Wu (1998), Smith $(1999)^{22}$ and Eun and Jin-gil (1999) used cointegration technique to examine the Purchasing Power Parity (PPP) theory.

Chinn (1999), Sichei, Gebreselasie and Akanbi (2005), and more recently, MacDonald and Ricci (2002) have employed the framework in modelling the Rand. With this theoretical framework, the hypotheses to be tested in this study are formally stated in a null format as follows: 
Ho1: The nominal USD ZAR exchange rate and indexed commodity prices or their first difference changes are not significantly related. $^{23}$

Ho2: There is no long run relationship between the nominal USD ZAR exchange rate and indexed commodity price series.

Ho3: There is no significant uni-directional and/or two-way causality between nominal USD ZAR exchange rates and indexed commodity prices or their first difference changes.

\section{4}

\section{Econometric methodology and data}

\subsection{Data}

For the exchange rate we employ monthly USD ZAR nominal exchange rate data, collected from the Thomson Reuters 3000 XTRA system. ${ }^{24}$ The period 1996-2010 is selected to capture the dynamics of the floating Rand and the four episodes of the Rand crises of 1996, 1998, 2001 and 2008. This choice of data is consistent with Simpson (2002). We transform the exchange rate data into an index $(2005 \mathrm{M} 6=100)$ coinciding with the base year for the commodity price index from the IMF and then into natural logarithms for ease of interpretation of regression coefficients. ${ }^{25}$

For commodity prices, we use the non-fuel commodity price index published by the IMF. $^{26}$ The IMF publishes a world exportearnings-weighted price index $(2005=100)$ for over forty primary commodities traded on various exchanges. The index has 35 commodities representing approximately 42.9 per cent of South Africa's exports (Ndlovu, X., 2010). This index excludes the effects of the weight of petroleum products (which have a weight of 53.6 per cent in the all-commodity index) which may bias our estimations. This choice of data is consistent with Chen and Rogoff (2003) and Simpson (2002). The USD denominated index is suitable for South Africa, which has its commodity exports invoiced in US Dollars. For ease of comparison with the exchange rate data we transform the data into natural logarithms. Figure 1 plots both variables. ${ }^{27}$

Figure 1

Log of USD ZAR and Commodity Price Index 1996 M1 to 2010 M3

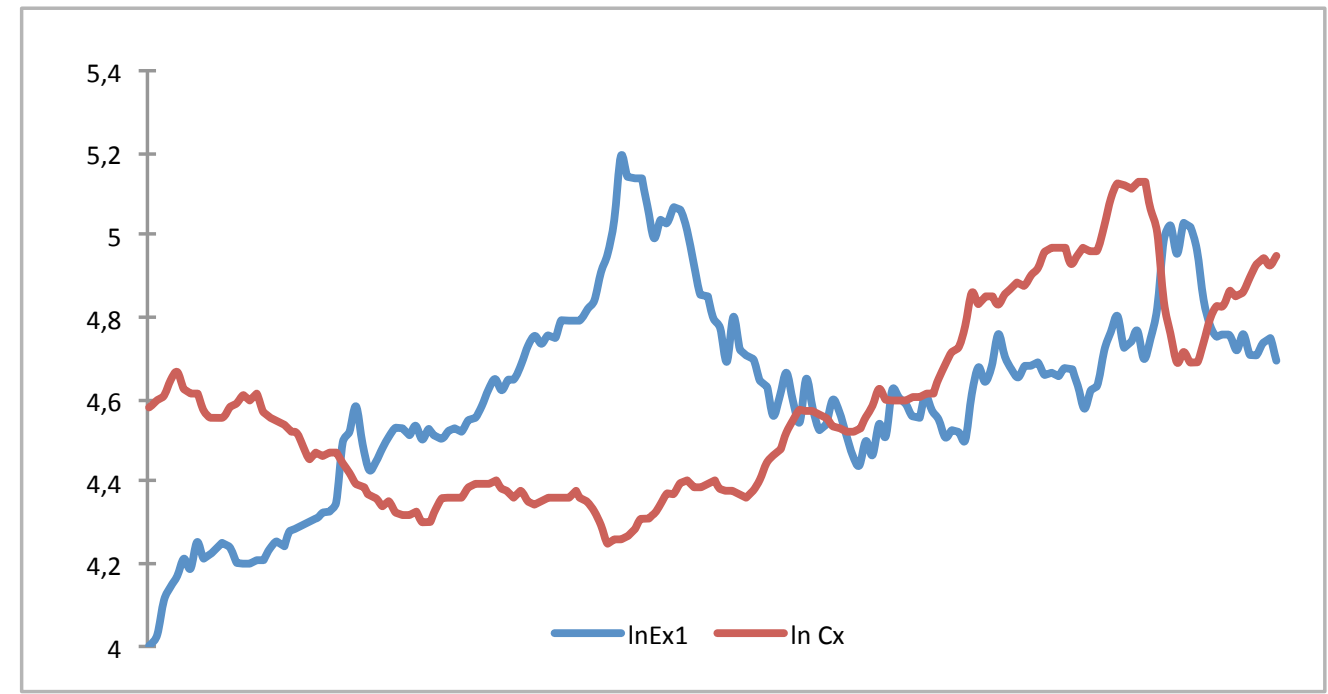

The plots in Figure 1 indicate the possibility of structural breaks in the series. This will be investigated in more detail in the context of the
Johansen test. In Figure 2 below we provide some brief discussion about the exchange rate over the sample period. 
Figure 2

History of the South African Rand 1965-2012

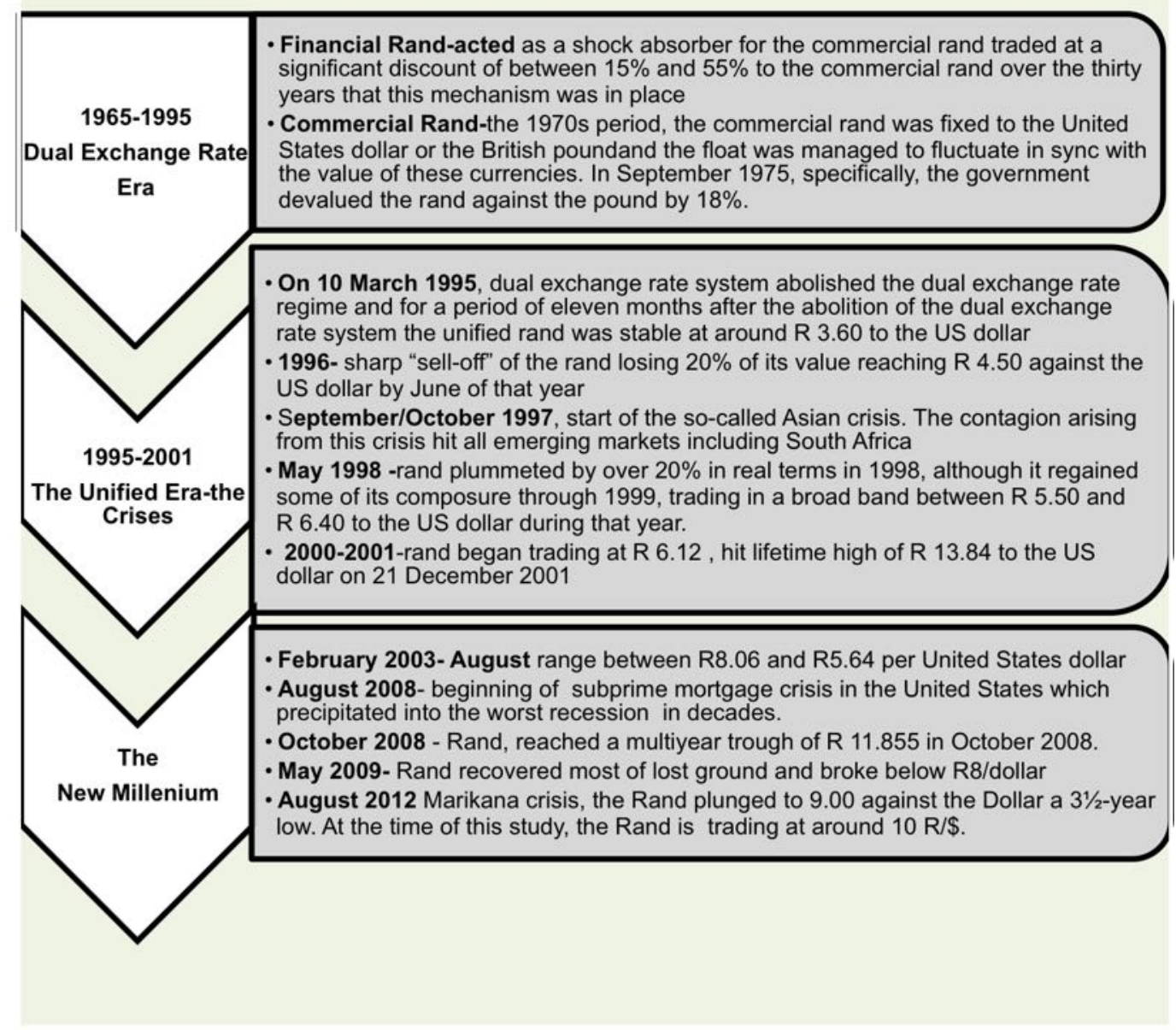

\subsection{Econometric methodology}

\subsubsection{Univariate characteristics of data}

We employ the ADF unit root and KPSS stationarity tests (Dickey \& Fuller, 1981 and Kwiatkowski, Philips, Schmidt and Shin 1992). Results are reported in Section 4.3. Here we employ an AR (1) model for the exchange rate series in equation (9). The model specified has an intercept $(\alpha)$ (a random walk with a drift), which allows for changes in the exchange rate to be non-zero over time.

$$
E_{\mathrm{t}}=\alpha+\beta E_{t-1}+e_{t}
$$

Equation (9) can be rewritten as:

$$
\begin{gathered}
\Delta E_{t}=\alpha+\rho E_{t-1}+\mathrm{e}_{t} \\
\text { where } \rho=\beta-1
\end{gathered}
$$

Such that the hypothesis that the exchange rate series have unit root can be represented as:

$$
H_{0}: \rho=0 \text { Against } H_{1}: \rho \neq 0
$$

For the commodity prices variable, we specify the AR (1) model as:

$$
C_{t}=\delta+\theta C_{t-1}+u_{t}
$$

Equation (12) can be re-written as:

$$
\begin{gathered}
\Delta C_{t}=\delta+\lambda C_{t-1}+u_{t} \\
\text { where } \lambda=\theta-1
\end{gathered}
$$

Such that the hypothesis that commodity prices have unit root can be represented as:

$$
H_{0}: \lambda=0 \text { Against } H_{1}: \lambda \neq 0
$$




\subsubsection{Engle-Granger test for cointegration and error correction modelling}

When the tests for unit root confirms that both exchange rate and commodity price series are non-stationary, we proceed to apply the EngleGranger and Johansen tests for cointegration (Engle \& Granger, 1987; Johansen, 1991). Unit root and cointegration in time series are important statistical properties that make sound economic sense in the manner in which variables are related.They may suggest that variables share common stochastic trends (Stock \& Watson, 1988). We proceed in the following manner:

First we run a regression using equation (15) (see Engle \& Granger, 1987):

$$
E_{t}=\alpha+\beta C_{t}+e_{t}
$$

The asymptotic distribution of $\beta$ is not standard, but the test suggested by Engle and Granger was to estimate $\hat{\beta}$ by OLS and the test for unit roots in: ${ }^{28}$

$$
\hat{e}_{t}=E_{t}-\alpha-\hat{\beta} C_{t}
$$

We specify an AR (1) model in terms of $\hat{e}_{t}$ in equation (17)

$$
\hat{e}_{t}=\phi+\mu \hat{e}_{t-1}+u_{t}
$$

Equation (17) can be re-written as:

$$
\begin{gathered}
\widehat{\Delta e}_{t}=\phi+\vartheta \hat{e}_{t-1}+u_{t}, \\
\text { where } \vartheta=\mu-1
\end{gathered}
$$

Such that Engle Granger Test for existence of cointegration amounts to the DF test of the hypothesis that:

$$
H_{0}: \vartheta \neq 0 \text { Against } H_{1}: \vartheta=0
$$

Failure to reject the hypothesis in equation (19) would imply that the USD/ZAR exchange rate and commodity price index are cointegrated. If the variables are cointegrated, we can apply Ordinary Least Squares (OLS) estimation of the VAR in equation (1) and (2) and obtain consistent long-run estimates of $\vartheta$ and $\mu$. The short-run relationship can be modelled through an Error Correction Model (ECM).

We rewrite the VAR in equations (1) and (2) in the form of a Vector Error Correction Model (VECM):

$$
\begin{aligned}
\Delta E_{t} & =\vartheta+\lambda e_{t-1}+\sum_{i=1}^{p} \delta_{i} \Delta E_{t-i}+\sum_{i=1}^{p} \omega_{i} \Delta C_{t-i}+\varepsilon_{t} \\
\Delta C_{t} & =\mu+\gamma u_{t-1}+\sum_{i=1}^{p} \psi_{i} \Delta C_{t-i}+\sum_{i=1}^{p} \tau_{i} \Delta E_{t-i}+\epsilon_{t}
\end{aligned}
$$

where $e_{t-1}$ and $u_{t-1}$ are lagged values of the error term from the cointegrating equations (7) and (8).

The VECM suggests that changes in exchange rates and commodity prices depend on deviations from a long-term equilibrium that is defined by the cointegrating relationship. The quantity $e_{t-1}$ or $u_{t-1}$ can be thought of as an equilibrium error and if it is non-zero, then the model is out of equilibrium and should 'correct' in the next period back to equilibrium. Thus the model captures short-run properties in the error term (Koop, 2006:175).

Rejection of the hypothesis associated with

equation (19) means that the series are both non-stationary but not cointegrated, and thus OLS is not a suitable estimation technique and it is likely to produce spurious regression problem. The problem may manifest itself in an apparently highly significant relationship between the exchange rate and commodity prices (even when $\beta=0$ in equation 15). This should be detected by a low Durbin Watson (DW) Statistic (Durbin \& Watson, 1971). ${ }^{29}$ It is more useful to reformulate the VAR in first differences of the series (Koop, 2006:178). We rewrite the VAR (p) in equations (1) and (2) by first differences: ${ }^{30}$

$$
\begin{aligned}
& \Delta E_{t}=\vartheta+\sum_{i=1}^{p} \gamma_{i} \Delta E_{t-i}+\sum_{i=1}^{p} \varphi_{i} \Delta C_{t-i}+e_{t} \\
& \Delta C_{t}=\mu+\sum_{i=1}^{p} \varrho_{i} \Delta C_{t-i}+\sum_{i=1}^{p} \sigma_{i} \Delta E_{t-i}+u_{t}
\end{aligned}
$$




\subsubsection{Lag length selection}

The Granger test depends critically on the choice of the lag length. An arbitrary choice of lag length could result in potential model misspecifications where too short a lag length may result in estimation bias while too long a lag causes a loss of degrees of freedom and thus estimation efficiency (Lee, 1997). Hafer and Sheehan (1989) find that the accuracy of forecasts from VAR models varies substantially for alternative lag lengths. We employed information criteria and lag exclusion test to determine the appropriate lag. The results are consistent and we therefore stick to the information criteria test. The three information criteria we used (Akaike, Schwarz \& HannanQuinn) soundly select one lag.

\subsection{Unit root and stationarity tests}

We apply the ADF and KPSS tests to test the null of a unit root and the null of stationarity respectively. It is well established that standard unit root tests such as $\mathrm{ADF}$ fail to reject the null hypothesis of unit root for many economic series (See Nelson \& Plosser, 1982). To complement the ADF test we apply the stationarity test proposed by Kwiatkowski et al. (1992). The KPSS test statistic is an LM type statistic, with the number of lags truncation selected automatically by Newey and West Bandwidth using Barlett Kernal spectral estimation method. The null hypothesis of stationarity is accepted if the value of the KPSS test statistic is less than its critical value at the conventional level of significance. The results of both the unit root and stationarity test are presented in Table 1. Using the 5 per cent level, we reject the null hypothesis of stationarity in the Table 1 below. As seen from the first differences, both exchange rates and commodity prices are nonstationary at the conventional level of significance. Further, the ADF test statistic is less negative at any of the chosen levels of significance at levels. However, the first differences are stationary. Thus both the ADF and KPSS confirm that the two series are I (1), justifying our test for cointegration in the next section.

Table 1

\begin{tabular}{|l|c|c|c|c|}
\hline \multicolumn{2}{|c|}{ Unit root and stationarity test } \\
\cline { 2 - 5 } \multicolumn{1}{c|}{} & \multicolumn{2}{|c|}{ ADF } & \multicolumn{2}{c|}{ KPSS } \\
\hline Levels & First differences & Levels & First differences \\
\hline Exchange rates & -2.1032 & -12.175 & 0.2372 & 0.07375 \\
\hline
\end{tabular}

${ }^{*}$ Critical values for KPSS at $1 \%, 5 \%$ and $10 \%$ are $0.2160,0.1460$ and 1.1190 respectively, including a constant and a trend. ADF critical values including a constant and a trend at $1 \%, 5 \%$ and $10 \%$ are -4.129 , 3.436 and -3.142 respectively.

\subsection{Engle Granger test for cointegration}

We present regression results of equation (18) in Table 2.

Using the DF test critical value of -2.58 , results suggest rejection of the null hypothesis set out in equation (19). This indicates that the error terms are non-stationary and nonhomoskedastic. Therefore there is no possibility that the series are cointegrated at 10 per cent level of significance. In order to check the robustness of our results we now also employ the Johansen test.

Table 2

Engle Granger test for cointegration

\begin{tabular}{|l|c|c|c|}
\hline \multicolumn{1}{|c|}{ Variable } & $\begin{array}{c}\text { Regression } \\
\text { coefficient }\end{array}$ & T-value & $\begin{array}{c}\text { Dickey Fuller critical } \\
\text { value at } \mathbf{1 0 \%}\end{array}$ \\
\hline Intercept & 0.0004 & 0.3836 & -2.58 \\
\hline Error term $\left(\hat{\mathrm{e}}_{\mathrm{t}-1}\right)$ & -0.0396 & -2.530 & -2.58 \\
\hline
\end{tabular}


Using the DF test critical value of -2.58 , results suggest rejection of the null hypothesis set out in equation (19). This indicates that the error terms are non-stationary and nonhomoskedastic. Therefore there is no possibility that the series are cointegrated at 10 per cent level of significance. In order to check the robustness of our results we now also employ the Johansen test.

\subsection{Johansen test}

The plots in Figure 1 indicate the possibility of structural breaks in the series. The presence of breaks can affect the asymptotic distribution of the test statistics. In line with Bai and Perron (2003), we allow multiple breaks in the series. ${ }^{31}$ Following this we construct dummy variables to account for the breaks and include these in the VAR. In the spirit of Johansen, Mosconi and Nielsen (2000) and more recently, Giles and Godwin (2012), we implement the Johansen cointegration test by accounting for breaks in the data. In this instance the asymptotic distribution of the trace test is different from what it would usually be without accounting for breaks. Table 3 reports the results of the Johansen trace test.

Table 3

Johansen cointegration test (trace)

\begin{tabular}{|l|c|c|c|c|}
\hline $\begin{array}{c}\text { Hypothesized } \\
\text { no. of CE(s) }\end{array}$ & Eigenvalue & $\begin{array}{c}\text { Trace } \\
\text { statistic }\end{array}$ & $\begin{array}{c}\mathbf{0 . 0 5} \\
\text { Critical value }\end{array}$ & Prob.** $^{* *}$ \\
\hline None & 0.055812 & 14.85512 & 25.87211 & 0.5866 \\
\hline At most 1 & 0.030518 & 5.206849 & 12.51798 & 0.5670 \\
\hline
\end{tabular}

Notes: Trace test indicates no cointegration at the 0.05 level. ${ }^{* *}$ MacKinnon-Haug-Michelis (1999) p-values

As can be seen in Table 3 above the null of cointegration is rejected for exchange rates and commodity prices, confirming the lack of long run relationship between the two series as shown by the Engle and Granger test.

\subsection{Estimating the VAR in first differences}

We present results from the estimation of equations (22) and (23) in Tables 4, 5, 6 and 7. The sequential lag length selection procedure employed reduces the model to a VAR (1) (results available on request). From Table 4, we note that commodity price changes belong to the exchange rate equation with an elasticity of -0.3264 , ceteris paribus. The regression coefficient has a negative sign, suggesting that a 1 per cent increase in commodity prices is associated with an exchange rate appreciation of 0.33 per cent thus lending credence to the commodity currency notion of the Rand. The $\mathrm{R}^{2}$ shows that commodity prices variability account for approximately 3.23 per cent of the variability in the exchange rate and is statistically significant at 10 per cent level. The $\mathrm{R}^{2}$ is not only very small, but also the elasticity of the exchange rate with respect to commodity price changes is significantly lower than those found in comparable OECD commodity exporting economies. ${ }^{32}$

Table 4

Exchange rate as dependent variable

\begin{tabular}{|l|r|r|r|r|c|}
\hline $\begin{array}{c}\text { Independent } \\
\text { variable } \\
\text { intercept }\end{array}$ & $\begin{array}{c}\text { Regression } \\
\text { coefficient }\end{array}$ & T-value & P-value & $\begin{array}{c}\text { Lower 90\% } \\
\text { C.L. }\end{array}$ & $\begin{array}{c}\text { Upper 90\% } \\
\text { C.L. }\end{array}$ \\
\hline & 0.0045 & 1.210 & 0.2281 & -0.0017 & 0.0107 \\
\hline$\Delta \mathrm{C}_{\mathrm{t}-1}$ & -0.3264 & -2.358 & 0.0195 & -0.5554 & -0.0974 \\
\hline$\Delta \mathrm{E}_{\mathrm{t}-1}$ & 0.0182 & 0.230 & 0.8183 & -0.1124 & 0.1488 \\
\hline
\end{tabular}

Estimated model: $\Delta E_{t}=0.0045+0.0182 \Delta E_{t-1}-0.3264 \Delta C_{t-1}$ 
Table 5

Analysis of variance on $\Delta E_{t}$

\begin{tabular}{|l|c|c|c|c|}
\hline \multicolumn{1}{|c|}{ Model Term } & $\mathbf{R}^{2}$ & F-Ratio & P-Value & Power (10\%) \\
\hline$\Delta \mathrm{C}_{\mathrm{t}-1}$ & 0.0323 & 3.136 & 0.0461 & 0.7140 \\
\hline$\Delta \mathrm{E}_{\mathrm{t}-1}$ & 0.0003 & 5.561 & 0.0195 & 0.7592 \\
\hline Model & 0.0364 & 0.053 & 0.8183 & 0.1089 \\
\hline
\end{tabular}

We present the results of the model with commodity prices as the dependent variable below. The results from Table 6 suggest that only the change in commodity prices lagged one month belong in the commodity prices determination equation. Changes in the exchange rate, despite having a negative sign, are statistically insignificant at the 10 per cent level of significance.

Table 6

Commodity prices as the dependent variable

\begin{tabular}{|l|c|c|c|c|c|}
\hline $\begin{array}{c}\text { Independent } \\
\text { variable }\end{array}$ & $\begin{array}{c}\text { Regression } \\
\text { coefficient }\end{array}$ & T-value & P-value & $\begin{array}{c}\text { Lower 90\% } \\
\text { C.L. }\end{array}$ & $\begin{array}{c}\text { Upper 90\% } \\
\text { C.L. }\end{array}$ \\
\hline Intercept & 0.0016 & 0.860 & 0.3909 & -0.0015 & 0.0101 \\
\hline$\Delta \mathrm{E}_{\mathrm{t}-1}$ & -0.0968 & -2.466 & 0.147 & 0.1617 & -0.0319 \\
\hline$\Delta \mathrm{C}_{\mathrm{t}-1}$ & 0.4312 & -2.466 & 0.0000 & 0.3173 & 0.5451 \\
\hline
\end{tabular}

Estimated model: $\Delta C_{t}=0.0016+0.4312 \Delta C_{t-1}-0.0968 \Delta E_{t-1}$

Table 7

Analysis of variance on $\Delta C$

\begin{tabular}{|l|c|c|c|c|}
\hline \multicolumn{1}{|c|}{ Model Term } & $\mathbf{R}^{\mathbf{2}}$ & F-Ratio & P-Value & Power (10\%) \\
\hline$\Delta \mathrm{E}_{\mathrm{t}-1}$ & 0.0278 & 6.082 & 0.1470 & 0.7914 \\
\hline$\Delta \mathrm{C}_{\mathrm{t}-1}$ & 0.1793 & 39.225 & 0.0000 & 1.0000 \\
\hline Model & 0.2412 & 26.382 & 0.0000 & 1.0000 \\
\hline
\end{tabular}

The $\mathrm{R}^{2}$ reading of 0.0278 suggests that exchange rate variability accounts for approximately 2.78 per cent of the variability in commodity prices. This number is not only small but also statistically insignificant at the 10 per cent level. The results suggest exogeneity in the determination of commodity prices with respect to the exchange rate and support the rejection of the 'currency commodity' hypothesis for South Africa. They compare well to the findings of Simpson (2002) for the Australian dollar.

\subsection{Granger causality tests}

We test hypotheses that Granger causality exists as set out in equations (22) and (23). First when the exchange rate is the dependent variable, results from Table 4 show that: $\varphi=$ -0.3264 .

The coefficient is statistically significant at the 10 per cent level of significance or better.
Accordingly, we fail to reject the hypothesis that changes in commodity prices Granger cause changes in the USD/ZAR exchange rate. The negative sign supports the hypothesis that the South African Rand is a commodity currency and changes in the commodity markets are contemporaneously reflected in the exchange rate.

From Table 6, we note that: $\sigma=-0.0968$.

This coefficient is, however, not only close to zero but statistically insignificant at the 10 per cent level. We therefore reject the hypothesis that changes in USD/ZAR exchange Granger causes changes in commodity prices. The $\mathrm{R}^{2}$ is also small and statistically insignificant at the 10 per cent level. This finding implies that the open economy model with endogenously determined commodity prices may not be suitable for South Africa. We surmise that South Africa is a price-taker in the world commodity markets. 
5

\section{Conclusions and suggestions for further research}

The paper extends the current literature on the importance of the commodity prices/exchange rate nexus for South Africa. We showed that there is a direct relationship between commodity price changes and exchange rate changes in South Africa; suggesting rejection of our first null hypothesis that the two variables are not related. The strength of the relationship is, however, significantly weaker than that found in other commodity exporting countries such as Australia. ${ }^{33}$

One key difference between OECD commodity exporters and South Africa comes from the Commodity Terms of Trade (CTT). ${ }^{34}$ South Africa is a substantial net importer of oil. ${ }^{35}$ This means that it is possible for the real exchange rate to depreciate in a commodity boom if the oil price accelerates faster than the price of the export basket of commodities. It has indeed been shown that the commodity terms of trade $(\mathrm{CTT})^{36}$ for South Africa has been very volatile since 2000 .

Another salient difference between the Rand and other OECD exchange rates comes from the global portfolio re-balance hypothesis. The 'flight to safety' theme of financial markets implies that managers of a global portfolios would typically 'fire-sale' higher risk emerging market assets (like South African equities and bonds) and simultaneously buy into safer haven assets in which commodities like gold and silver are classified. ${ }^{37}$ In down trending financial markets therefore, portfolio managers would typically sell off South African assets (causing the Rand to depreciate) while investing in commodities like gold (thus causing a boom in commodity markets). Such episodes were observed in the 2008-2010 gold price boom which was accompanied by a huge depreciation of the Rand. In the absence of an error correction mechanism, this disconnect may be prolonged.

The nominal primary data in the series in this study are not cointegrated. Findings by other scholars suggest that the ratio of commodity currencies and commodity prices is at least mean reverting (e.g. Hughes, 1994).
Further, cointegration investigations may benefit from the use of longer time frames.

Our findings on Granger causality support the rejection of null hypothesis 3 that there is zero uni-directional and/or two-way causality between the changes in the two assets classes and suggest that changes in the commodities market lead changes in the exchange rate markets. This conclusion, consistent with Simpson (2002), suggests that an open economy assumption of endogenously determined commodity prices may be inappropriate when modelling exchange rate movements in South Africa. This evidence, however, is at odds with the conclusion of Clements and Fry (2006) who concluded that commodity currency models failing to account for endogeneity between currency and commodity returns may be miss specified.

For firms with commodity and currency exposures, a conventional one size fits all strategy for all commodity currencies may be incorrect. Firms may need to consider hedging with synthetic contracts and option based contracts, as has been demonstrated that the relationship between the two asset classes is dynamic and changing over time. In the absence of an error correction mechanism, hedging between the two markets may be partial (for example, in proportion to the degree of systematic risk in the market). For specific kinds of firm decisions one would need to undertake further research on the effect of individual commodities prices (for example, gold, crude oil and coal) instead of a composite index.

Monetary policy makers may find forward and futures prices useful leading indicators of future commodity price movements (and therefore exchange rates) in a logical manner. For their part, monetary policy makers must manage the commodity price risk to the economy in a manner that mitigates price and commodity concentration risk on exports.

There are a number of ways the work in this paper could be extended. One would be to consider a more structural approach that also includes other variables such as inflation and terms of trade fluctuations. We leave this for further research. 


\section{Endnotes}

1 Examples include MacDonald and Ricci (2002), Cashin, Cespedes and Sahay (2004) who employ real data in their analysis.

2 For example, Ndlovu, X (2010) shows that commodity exports excluding precious metals constituted 42.9 per cent of South African total exports in 2010. See also Bodart, Candelon and Carpantier (2012). Cashin Cespedes and Sahay (2004) report that gold, coal and iron contributed 46 per cent, 20 per cent and 5 per cent respectively to total exports for South Africa in the period 1991-99.

3 See Chen (2002).

4 We expect correlation and the regression coefficient to be negatively signed when the Rand denominated exchange rate (USD ZAR) is regressed on US Dollar denominated commodity prices.

5 The study's intention is to capture the effect of speculative bubbles in the two asset markets. We find that there has been some work already done on the Rand and commodity prices, employing real variables. Examples include Cashin, Cespedes and Sahay (2004) and MacDonald and Ricci (2002).

6 That is, one that moves in sympathy with commodity prices.

7 The assumptions of a dominant commodity producer invoicing in domestic currency make this hypothesis implausible in reality. For example, Chen (2002) argues that commodity price fluctuations essentially represent a source of exogenous shocks to the terms of trade of three OECD countries. Further, Chen and Rogoff (2003) provide discussions of and tests fo the exogeneity of commodity prices in Australia, Canada, and New Zealand. They also show that world commodity prices better capture the exogenous component of terms of trade shocks than standard measures of terms of trade, an argument countered by Clements and Fry (2006) who argue that commodity currencies models failing to account for endogeneity between currency and commodity returns may be misspecified.

8 A key implicit assumption here is that foreign demand for commodities exported by the commodity exporting country is price-elastic.

9 He finds long-run elasticities of exchange rates with respect to commodity prices of $0.92,0.46$ and 1.51 for Australia, Canada and New Zealand respectively.

10 Where he uses the European definition of the exchange rate; that is units of domestic currency per units of foreign currency.

11 See Appendix 1 of Ndlovu (2010) for a survey of recent studies.

12 See Appendix 1 of Ndlovu (2010) for a survey of recent studies.

13 Based on Blundell-Wignall and Gregory (1990).

14 South Africa is a fairly open economy with trade/GDP ratio 40 year average of 52.5 per cent, comparable to OECD economies like Greece, Poland and France. See http://www.dti.gov.za/econdb/raportt/ra5385KK.html. The economy (measured by GDP) is the largest in Africa, ranked $32^{\text {nd }}$ in the world with GDP estimated at nearly USD300 billion by IMF.

15 See http://www.imf.org/external/pubs/ft/weo/2010/01/weodata/weorept.aspx.

16 Examples could include oil from Saudi Arabia, wool from Australia and several minerals from Australia such as iron ore, tantalite and possibly coal. This situation is well known in international economics, manifesting in the formation of cartels among exporting nations and price-stabilisation schemes.

17 See Sjaastad (1985, 1989, 1990, 1998a,b, 1999, 2000, 2001) and Sjaastad and Scacciavillani (1996). See also Ridler and Yandle (1972). For a recent application, see Keyfitz (2004).

18 This is the VAR methodology used by Simpson (2002).

19 The Granger representation theorem (Koop, 2006:174)

20 Clive Granger, the UCSD econometrician, gets all the credit for this, even though the notion was apparently first advanced by Weiner twenty or so years earlier.

21 However, there are serious shortcomings of the methodology - for example, Granger causality is a special type of causality and may not measure true causality (i.e. temporal versus true causality); also, the results of Granger causality test depend crucially on the appropriate selection of the variables.

22 Martinez (1999) applied cointegration and vector autoregression techniques to Mexican international reserves, exchange rates and changes in domestic credit. As a matter of interest, Martinez discovered that, despite the presence of nonstationarity, a long-run relationship existed between these variables.

23 Smith (1999) found that for many commodities floating exchange rates did not cause a significant increase in overall domestic currency price variation when also considering a good's overseas price variation.

24 Throughout this study we employ the European definition of the exchange rate, that is, ZAR/USD1.

25 www.thomsonreuters.com.

26 Such that $S_{t}=\frac{S_{t}}{S_{t B}} * 100$

27 where $S_{t}=$ nominal USDZAR at month $t$.

$28 S_{t B}=$ nominal exchange rate for the base year and month: $2005 \mathrm{M} 6$.

29 and $\ln \left(S_{t}\right)=E_{t}$

30 where $S_{t}=$ nominal USDZAR at month

31 and $E_{t}=$ natural logarithm of exchange rate index at month $t$

32 Source: https://www.imf.org/external/np/res/commod/Table2-091410.pdf.

33 Note here the exchange rate is expressed in terms of the Rand, that is, the USD is priced in Rand. Plotted with commodity price index priced in dollars therefore, the relationship is expected to be negative.

34 Using the Dickey Fuller methodology, Dickey and Fuller (1981).

35 High $R^{2}$ and very low Durbin-Watson statistics $\left(R^{2}>\mathrm{d}\right)$, see Durbin and Watson (1971).

36 Note that this VAR is implied by equations (1) and (2). Hence equation (22) depicts the standard 'commodity currency' argument while equation (23) shows the 'currency commodity' notion of Clements and Fry (2006). 
37 Results available on request.

38 See Appendix 1 of Ndlovu (2010) for comparisons.

39 For example, Simpson (2002) found the negative elasticity of exchange rate changes with respect to commodity price changes to be -0.8952 , with $\mathrm{R}^{2}$ of 0.4498 , statistically significant at 10 per cent level of significance.

40 Defined here as the price index of South Africa's commodity export basket deflated by oil price; see SARB Report on policy implications of commodity prices movements, (2008).

41 Estimated at 67 per cent of consumption by Global trade atlas, see http://www.gtis.com/english/GTIS GTA.html.

42 See SARB Report on policy implications of commodity prices movements, (2008).

43 World Gold Council 2010 Q1 Report http://www.gold.org/assets/file/pub_archive/pdf/GDT_Q1_2010.pdf.

\section{References}

AREZKI, R., DUMITRESCU, E., FREYTAG, A. \& QUINTYN, M. 2012. Commodity prices and exchange rate volatility: Lessons from South Africa's capital account liberalization. IMF Working Paper, WP/12/168. BAI, J. \& PERRON, P. 2003. Computation and analysis of multiple structural change models. Journal of Applied Econometrics, 6:72-78.

BHUNDIA, A. \& RICCI, L. 2004. The rand crises of 1998 and 2001: What have we learned? IMF Working Paper, No. 03/252. Washington: International Monetary Fund.

BLEANEY, M. 1996. Primary commodity prices and the real exchange rate: the case of Australia 1900-91. The Journal of International Trade and Economic Development, 5(1):35-43.

BLUNDELL-WIGNALL, A. \& GREGORY, R.G. 1990. Exchange rate policy in advanced commodity exporting countries: the case of Australia and New Zealand. OECD Department of Economics and Statistics, Working Paper, No 83.

BODART, V., CANDELON, B. \& CARPANTIER, J.-F. 2012. Real exchanges rates in commodity producing countries: a reappraisal. Journal of International Money and Finance, 31:1482-1502.

CASHIN, P., CÉSPEDES, L. \& SAHAY, R. 2004. Commodity currencies and the real exchange rate. Journal of Development Economics, 75:239-68.

CHABAN, M. 2009. Commodity currencies and equity flows. Journal of International Money and Finance, 28:836-852.

CHEN, Y. 2002. Exchange rates and fundamentals: evidence from commodity economies. Mimeograph, Harvard University.

CHEN, Y. \& ROGOFF, K.S. 2003a. Commodity currencies and empirical exchange rate puzzles. IMF Working Paper, 02/27. Washington: International Monetary Fund.

CHEN Y. \& ROGOFF, K.S. 2003b. Commodity currencies. Journal of International Economics, 60:133-169.

CHEN Y., ROGOFF, K.S. \& ROSSI, B. 2010. Can exchange rates forecast commodity prices? Quarterly Journal of Economics, August:1145-1195.

CHENG, B.S. 1999. Beyond the purchasing power parity: testing for cointegration and causality between exchange rates, prices and interest rates. Journal of International Money and Finance, 18:911-924.

CHEUNG, Y. \& LAI, K. 1993a. Long-run purchasing power parity during the recent floating. Journal of International Economics, 34:181-192.

CHEUNG, Y. \& LAI, K. 1993b. Finite sample sizes of Johansen's likelihood ratio tests for cointegration. Oxford Bulletin of Economics and Statistics, 55:313-328.

CHINN, M.D. 1999. A monetary model of the South African rand. The African Finance Journal, 1(1):69-91.

CLEMENTS, K. \& FREEBAIRN, J. 1991. Exchange rates and Australian commodity exports. Monash University, Centre of Policy Studies.

CLEMENTS, K.W. \& FRY R. 2006. Commodity currencies and currency commodities. CAMA Working Paper Series, 19.

DE GREGORIO, J. \& WOLF, H. 1994. Terms of trade, productivity and the real exchange rate. NBER Working Paper, 4807 Cambridge, MA.

DICKEY, D.A. \& FULLER, W.A. 1981. Likelihood ratio statistics for autoregressive time series within a unit-root. Econometrica, 49:1022-1057.

DORNBUSCH, R. 1976. Expectations and exchange rate dynamics. Journal of Political Economy, 4:11611176. 
DURBIN, J. \& WATSON, G.S. 1971. Testing for serial correlation in least squares regression-111. Biometrika, 58:1-42.

EICHENGREEN, B. ROSE, A. \& WYPLOSZ, C. 1996. Contagious currency crises: First tests. Scandinavian Journal of Economics, 98(4):463-84.

ENGLE, R.F. \& GRANGER, C.W.J. 1987. Cointegration and error correction: representation, estimation and testing. Econometrica, 55:251-276.

EUN, C.S. \& JIN-GIL, J. 1999. International price level linkages: evidence from the post Bretton Woods era. Pacific Basin Finance Journal, 7:331-349.

FRANKEL, J. 2007a. Making inflation targeting appropriately flexible. Unpublished Presentation at SA National Treasury, Pretoria 16th January 2007.

FRANKEL, J. 2007b. On the rand: Determinants of the South African exchange rate. South African Journal of Economics, 75(3):425-441.

FRANKEL, J. \& ROSE, A. 1995. Empirical research on nominal exchange rates. In Grossman, G., Rogoff, K. (eds.) Handbook of international economics 3. Amsterdam: Elsevier Science:1689-1729.

FROOT, K. \& ROGOFF, K. 1995. Perspectives on PPP and long-run real exchange rates. In Grossman, G. and Rogoff, K. (eds.) Handbook of international economics 3. Amsterdam: Elsevier Science:1647-88.

GILES, D.E. \& GODWIN, R.T. 2012. Testing for multivariate cointegration in the presence of structural breaks: P-values and critical values. Applied Economics Letters, 19:1561-1565.

GRANGER, C.W.J. 1988. Some recent developments in a concept of causality. Journal of Econometrics, 39:199-211.

HAFER, R.W. \& SHEEHAN, R.G. 1989. The sensitivity of VAR forecasts to alternative lag structures. International Journal of Forecasting, (3):399-408.

HATZINIKOLAOU, D. \& POLASEK, M. 2003. A commodity currency view of the Australian Dollar: a multivariate cointegration approach. Journal of Applied Economics, III(1):81-99.

HUGHES, B. 1994. The climbing currency. Research Publication, 31. Committee of Economic Development: Australia.

IM, K.S., PESARAN, H.M. \& SHIN, Y. 1995. Testing for unit-roots in heterogeneous panels. Working Paper, Cambridge University.

JOHANSEN, S. 1991. Estimation and hypothesis testing of cointegration vectors in Gaussian vector autoregressive models. Econometrica, 59(6):1551-1580.

JOHANSEN, S., MOSCONI, R. \& NIELSEL, B. 2000. Cointegration analysis in the presence of structural breaks in the deterministic trend. Econometrics Journal, 3:216-249.

KABUNDI, A. \& SCHALING, E. 2013. On the rand: a trade-off between exchange rate pass-through and the trade balance? Mimeo, University of Johannesburg.

KEYFITZ, R. 2004. Currencies and commodities: modelling the impact of exchange rates on commodity prices in the world market. Working Paper, Development Prospects Group, World Bank.

KOOP, G. 2006. Analysis of financial data. New York: John Wiley and Sons.

KWIATKOWSKI, D., PHILLIPS, P.C.B, SCHMIDT, P. \& SHIN, Y. 1992. Testing the null hypothesis of stationarity against the alternative of a unit root. Journal of Econometrics, 54:159-178.

LEE, J. 1997. Money, income and a dynamic lag pattern. Southern Economic Journal, 64:97-103.

MACDONALD, R. \& RICCI, L. 2002. Estimating the real equilibrium exchange rate for South Africa. Strathclyde University and IMF, IMF Working Paper.

MADDALA, G.S. \& WU, S. 1998. A comparative study of unit-root tests with panel data and a new simple test. Oxford Bulletin of Economics and Statistics, 61:631-52.

MACKINNON, J.G., HAUG, A.A \& MICHELIS, L. 1999. Numerical distribution functions of likelihood ratio tests for cointegration. Journal of Applied Econometrics, 14(5):563-77.

MARTINEZ, J DE LA CRUZ 1999. Mexico's balance of payments and exchange rates. The North American Journal of Economics and Finance, 10:401-421.

MEESE, R.A. 1990. Currency fluctuations in the post-Bretton Woods era. Journal of Economic Perspectives, 4.1:117-134. 
MEESE, R.A. \& ROGOFF, K. 1983. Empirical exchange rate models of the seventies: Do they fit out of sample? International Economic Review, 14:3-24.

NDLOVU, X. 2010. The relationship between the South African rand and commodity prices: examining cointegration and causality. MM finance dissertation, Wits Business School.

NELSON, C. \& PLOSSER, C.I. 1982. Trends and random walks in macroeconomic time series: some evidence and implications. Journal of Monetary Economics, 10(2):139-162.

OBSTFELD, M. \& ROGOFF, K.S. 1996. Foundations of international macroeconomics. Cambridge, MA: MIT Press.

PILBEAM, K., 1998. Exchange rate determination: theory, evidence and policy. International Finance, $\left(2^{\text {nd }}\right.$ ed.) London: MacMillan Business

RIDLER, D. \& YANDLE, C.A. 1972. A simplified method for analysing the effects of exchange rate changes on exports of a primary commodity. IMF Staff Papers, 19:550-78.

SARB. 2008. Report on Policy implications of Commodity Prices Movements.

SICHEI, M., GEBRESELASIE, T. \& AKANBI, O. 2005. An econometric model of the rand-US dollar nominal exchange rate, University of Pretoria Working Paper, 14.

SIMPSON, J.L. 2002. The relationship between commodity prices and the Australian dollar EFMA 2002 London Meetings. Available at: SSRN: http://ssrn.com/abstract=314872 or doi:10.2139/ssrn.314872.

SIMS, C.A. 1980. Macroeconomics and reality. Econometrica, 47:1-48.

SJAASTAD, L.A. 1985. Exchange rate regimes and the real rate of interest. In M. Connolly and J. McDermott (eds.) The economics of the Caribbean basin. New York: Praeger.

SJAASTAD, L.A. 1989. Debt, depression, and real rates of interest in Latin America. In Brock, P.L., Connolly, M., Gonzalez-Vega, C. (Eds.) Latin American debt and adjustment. Praeger: New York. SJAASTAD, L.A. 1990. Exchange rates and commodity prices: the Australian case. In Clements, K.W., Freebairn, J. (Eds.) Exchange rates and Australian commodity exports. Center for Policy Studies, Monash University: Clayton, Vic.

SJAASTAD, L.A. 1998a. On exchange rates, nominal and real. Journal of International Money and Finance, 17(3):407e439. Reprinted in Manzur, M. (Ed.), Exchange Rates, Interest Rates and Commodity Prices. Edward Elgar: Cheltenham UK and Northampton, Mass, 2002.

SJAASTAD, L.A. 1998b. Why PPP real exchange rates mislead. Journal of Applied Economics, 1(1): $179 \mathrm{e} 207$.

SJAASTAD, L.A. 1999. Exchange rate management under the current tri-polar regime (Lim Tay Boh Lecture, September 1998, National University of Singapore). Singapore Economic Review, 43(1):1e9. SJAASTAD, L.A. 2000. Exchange rate strategies for small countries. Zagreb Journal of Economics, 4(6): 46e51.

SJAASTAD, L.A. 2001. Some pitfalls of regionalization. The Journal of the Korean Economy, 2(2).

SJAASTAD, L.A. \& SCACCIAVILLANI, F. 1993. The price of gold and exchange rates. Mimeograph, University of Chicago, October.

SJAASTAD, L.A. \& SCACCIAVILLANI, F. 1996. The price of gold and exchange rates, Journal of International Money and Finance, 15:879-897.

SMITH, C E., 1999. Exchange rate variation commodity price variation, and the implications for international trade. Journal of International Money and Finance, 18(3):471-479.

STOCK, J. \& WATSON, M. 1988. Testing for common trends. Journal of American Statistical Association, 83:1097-1107.

SWIFT, R. 2004. Exchange rate changes and endogenous terms of trade effects in a small open economy. Journal of Macroeconomics, 26:737-745.

WORLD GOLD COUNCIL. 2010. Q1Report. Available at: http://www.gold.org/assets/file/pub_archive/ pdf/GDT_Q1_2010.pdf.

WU, Y. 1996. Are real exchange rates stationary? Evidence from a panel data test, Journal of Money, Credit and Banking, 28:54-63.

WU, Y. \& CHEN, S-L. 1999. Are real exchange rates stationary based on panel unit-root tests? Evidence from Pacific basin countries. International Journal of Finance and Economics, 243-252. 